\title{
HERALDIC AND VEXILOLOGICAL COMPOSITIONS IN TOURIST PRESENTATIONS OF HERITAGE MONUMENTS - CASE STUDY SFANTUL GHEORGHE-CEL-NOU CHURCH FROM BUCHAREST
}

DOI: https://doi.org/10.18509/GBP210377s

UDC: 338.483.12:930.85(498.11)

\author{
Laurentiu-Stefan Szemkovics ${ }^{1}$ \\ Andrei Ducman ${ }^{2}$ \\ Camelia Teodorescu ${ }^{2}$ \\ Bogdan Petre ${ }^{3}$ \\ Alina Viorica Dumitrascu ${ }^{3}$ \\ ${ }^{1}$ National Central Historical Archives, Bucharest, Romania \\ ${ }^{2}$ University of Bucharest, Faculty of Geography, Department of Human and Economic \\ Geography; Bucharest, Romania CAIMT (Research Center for Integrated Analysis and \\ Territorial Management), University of Bucharest, Romania \\ ${ }^{3}$ University of Bucharest, Faculty of Geography, "Simion Mehedinti" Dochtoral Scool, \\ Bucharest, Romania
}

\begin{abstract}
The tourist presentations have the role of attractig attention due to the uniqueness of the information provided. Heraldic compositions are quite appealing and can become important elements in the discourse of a tourist presentation. Our study aims to highlight the coats of arms and the flag embroidered, sewn, engraved, painted, sculpted, cast or moulded, woven, objects that exist at the St. Gheorghe-Nou Church in Bucharest, the place where, among others, there are buried the rulers of Wallachia, Constantin Brancoveanu (1688-1714) and Ioan Mavrocordat (1716-1719). The funeral service of the poet Mihai Eminescu took place at this church, which is famous as a monument of Brancoveanu art in the Romanian capital-city. For the preparation of this study we have researched the church building, the bell, the frontispiece, the inscription, the perforated railings of the front porch and the staircase at the back entrance, the tombstone of Constantin Brâncoveanu's tomb, the scraper cover lid of the tomb containing the relics of Constantin Brâncoveanu, a few tetrapodes, the iconostasis, the carpet, the tablecloths, the curtains and the special curtain (the church flag) inside it. Regarding the actual description of the different types of coats of arms and the flag, we have complied with the heraldic and vexillological norms. We have taken into account the interest that these testimonies may arise in tourists, pilgrims, teachers, pupils and students alike, especially since the vexillological and heraldic sources can serve both to a better understanding of some historical phenomena and to distinguishing the symbols by which the ctitors and artists expressed their thoughts and aspirations. Our study is an impetus for the detection, analysis and placement in the scientific circuit and other sources of this kind, still unknown to tourists and to the general public.
\end{abstract}

Keywords: St. Gheorghe-Nou, coat of arms, flag, heraldry, vexillology, tourism.

\section{INTRODUCTION}

At Sfântul Gheorghe Square, at the zero kilometer of Bucharest city, there has been guarding, for centuries, the church called Sfântul Gheorghe-Nou (The New Saint Ghorge 
Church), an important monument of Romanian art and wit, that is dedicated to the patron saints: Saint George the Great Martyr [2], Saint Hierarch Nicolae, The Holy Martyr Saints of Brâncoveni and the Holy Pious Parascheva. Constantin Brâncoveanu, the ruler of Walachia / Țara Româneasca (1688-1714), built, between 1705-1707, the Sfântul Gheorghe-Nou Church [3] on the place of an older edifice founded during the 16th century by Dobruş Banul [2], [9], [11], [18]. St. Gheorghe-Nou Church imitates, to greater proportions, the model of the church of Hurezi Monastery [11], "the pearl of Brâncoveanu style architecture" [2], being the largest building founded within Brâncoveanu ruling period [8], [12] from the capital-city of Romania. In a different perspective, the craftsmen from Hurezi Monastery [4], [15] who also worked to build the Church of Sfântul Gheorghe-Nou, were: Istrate - wood carpenter, Manea - bricklayer, Pârvu Mutu - painter [2], [17] and Vucașin Caragea - stonemason [10].

The church was consecrated on June 29, 1707, on the feast of the Holy Apostles Peter and Paul, in the presence of Hrisant Nottara, the patriarch of Jerusalem [2]. In the church, there is yet the tomb of Constantin Brâncoveanu [1], [2], [6], [7], [9], [11], [17], [20], although, during his lifetime, he had prepared a splendid white marble sarcophagus at the Monastery Hurezi where, according to the will of the ruler, his earthly remains would have to be rested [19]. In the summer of 1720, under favorable circumstances, Mrs. Marica, the widow of Constantin Brâncoveanu, displaced the ruler's remains in Bucharest city, where she deposited them with great respect in a specidfically - built tomb inside St. Gheorghe- Nou' s Church [2], [8], [17], near the tomb of the fanariot Mr. Ioan Mavrocordat [1], [11]. In 1729, the lady Marica Brâncoveanu was also buried with her martyr husband, in the same church of Saint Gheorghe-Nou [2].

At this church, pilgrims, tourists, pupils, students, teachers can discover architecture, painting, sculpture, religious art, a flag (religious flag), coats of arms and other traces, materials that all refer to the objective worth visiting. I have described and rendered the heraldic and vexillology insignia and particular symbols preserved at this church, which have been embroidered, engraved, painted, cast, woven, sculpted on the building and on the objects from outside and inside it (positioned, for the most part, from right to left and in counterclockwise direction). We did not insist on their importance as historical sources. We insisted on the description, reproduction and symbolism of the flag and coats of arms, which may contribute to highlighting the artistic activity.

\section{METHODOLOGY}

Regarding the method performed in this study, we went through the following steps: 1. Identification of the Church of St. Gheorghe-Nou in Bucharest where there is located, or which owns such heraldic and vexillology compositions; 2. Visiting the building and researching these testimonies, whether they were reproduced on the frontispiece building, of stone, wood, metal, marble slabs, carpets, curtains, tablecloths or any other material; 3. Analysis of the coats of arms and the church flag in accordance with heraldic norms and vexillology; 4.

Bringing these sources to the attention of the public concerned, through various specialized studies, events, visits, but also by promoting, for tourism purposes, heraldic, vexillology, as well as for the importance and remembering of the institution that owns them. 


\section{RESULTS}

A. On the vault on the frontispiece of the church (where Constantin Brâncoveanu, as well as his four sons, the counselor Ianache, too, and Jesus Christ in a position of glory (fig. 1), are all painted), at the base of its arch, on one side and on the other, there is painted twice in two round shields, with golden borders, on a red background, the heraldic coat of arms of Wallachia: on the left, the bird, rendered in full and in front-viewed position, with wide - open wings and flying downwards, standing with its feet on a mountain, with its body facing to the right side, his head turned to the left, holding a cross in its beak, and to the right, the same bird, only shown with the body towards senestra and the head facing right side, all golden. Above the two shields there appears twice as well, in other shields similar to the first, the coat of arms of the Cantacuzino family: the bicephalous eagle [5], crowned with an open crown, holding in his claws the insignia of power: on the right the mace, to the left the sword, all golden (fig. 2).
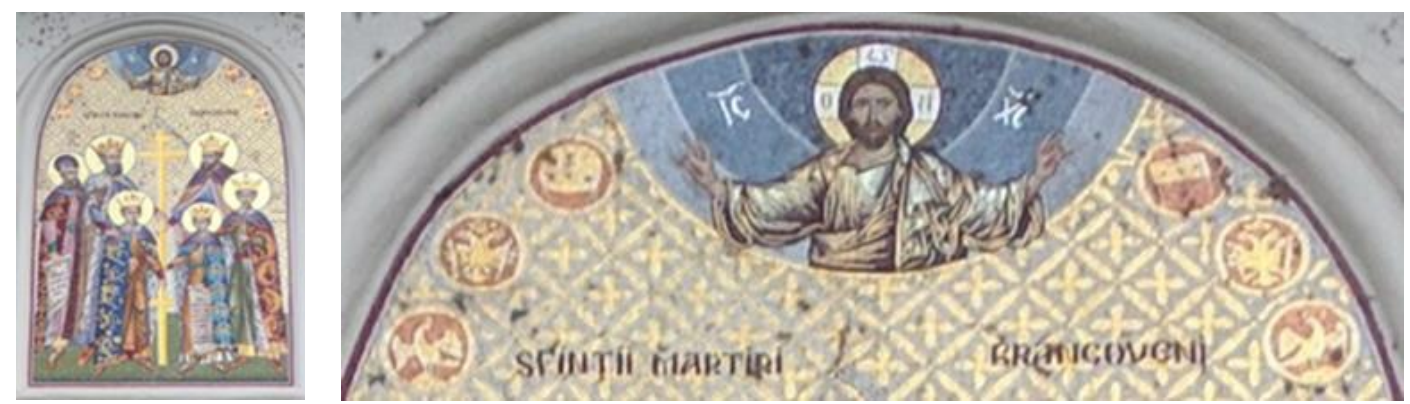

Figure 1. and Figure 2. The vault on the frontispiece of the Church of St. Gheorghe-Nou from Bucharest, including, at the top, the heraldic coats of arms of Wallachia and the Cantacuzino family.

B. The porch, in the shape of a rectangle, arranged transversely on the axis of the church, surrounded by a stone parapet (Cărămizaru, 2014) that rises upon fourteen columns of stone (eight frontally and three on each side), which are based on a rhododendron flower carved in excision (relief), has, on the front, left and right sides, three railings, with acanthus plants with leaves and flowers, perforated, but also with the heraldic coat of arms of Wallachia [2] located on two of them, as follows: on the right side of the front railing (fig. 4), the crucified bird (fig. 3) and on the left railing (fig. 5), the same bird, but rendered with its head turned to the right wing (fig. 6) [15]. The staircase leading to the back door of the church also has a railing on which there is carved, by piercing, framed by acanthus rods, the crucified bird flanked, high, by the sun and crescent moon (fig. 7).

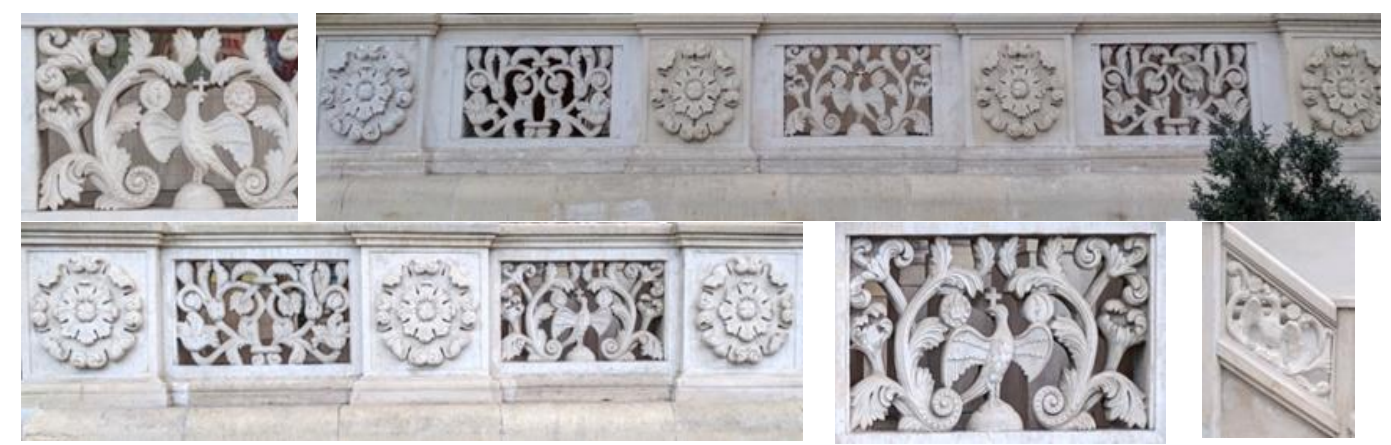

Figure 3., Figure 4., Figure 5. Figure 6. and Figure 7. The heraldic coat of arms of Wallachia on the railing on the right front, on the railing on the left side of the porch and on the railing of the access staircase to the back door of the Church St. Gheorghe-Nou from Bucharest 
C. On the inscription from 1699 [2] of the church (fig. 9) there is sculpted again the heraldic coat of arms of Wallachia (fig. 8). Above the front door of the church, framed, on the flanks, by acanthus plants with leaves and flowers and, below, two cherubim (fig. 11), the same coat of arms is carved as above (fig. 10).
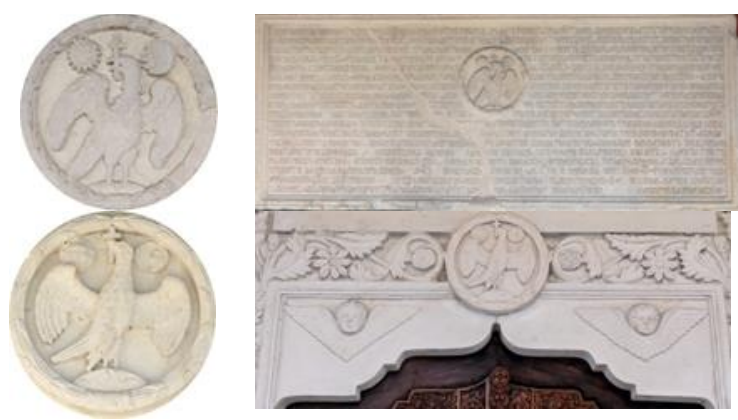

Figure 8. Figure 9. Figure 10. and Figure 11.. The heraldic coat of arms of Wallachia on the inscription from 1699 and in the frame above the door at the front entrance of the Church of St. Gheorghe-Nou in Bucharest.

D. On the gilded canopy, on the right side of the narthex of the church (fig. 14), worked in Brâncoveanu's style, which protects the casket, made of gilded silver, containing the relics of St. Constantin Brâncoveanu [2], in two rectangular frames, positioned above the twisted pillars, there are represented, in two oval shields, surrounded by acanthus plants with leaves and flowers, in the left one (fig. 13) - the coat of arms of Wallachia [13] (fig. 12), while in the right one (fig. 15) - the coat of arms of the Cantacuzins (fig. 16). On the inside of the crypt lid / scraper cover (fig. 18) mentioned above, decorated with acanthus ornaments and with three oval medallions, in the central one appearing the bust of the voivode Constantin Brâncoveanu, guarded, on the left (fig. 17) and on the right (fig. 19), by two crossed birds similar to those described above, rendered with the heads facing frontwards and facing the ruler. On the outside of the crypt lid / scraper cover (fig. 21) having engraved, in the center, the Holy Martyr Constantin Vodă (voivode) Brâncoveanu holding the cross in his right hand, while in his left - a deed act, showed un-rolled, in the middle of the edge, framed by acanthus plants with leaves and flowers, there appears the specific family coat of arms of the Cantacuzinos (fig. 20).
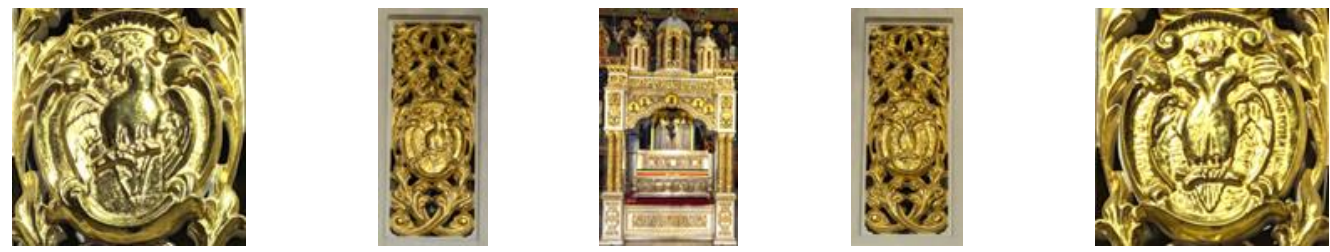

Figure 12. Figure 13. Figure 14. Figure 15. and Figure 16.. The heraldic coat of arms of Wallachia in the frame on the left side and the coat of arms of the Cantacuzinos in the frame on the right side of the canopy that protects the chest with the relics of Constantin Brâncoveanu.
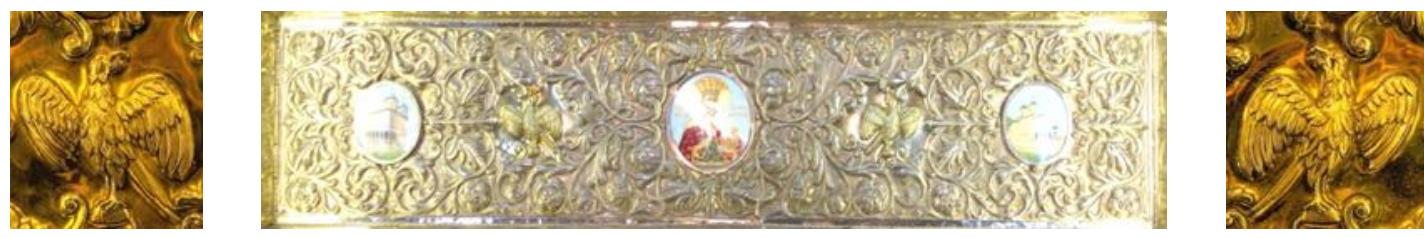

Figure 17. Figure 18. and Figure 19. The heraldic bird of Wallachia (in two hypostases) on the inside of the lid of the crypt containing the relics of Constantin Brâncoveanu. 


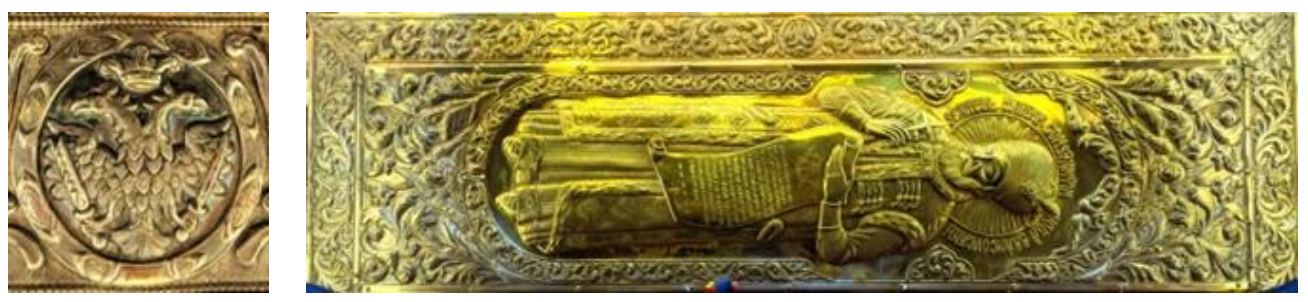

Figure 20. and Figure 21. The coat of arms of the Cantacuzino family on the outside of the scraper lid with the relics of Constantin Brâncoveanu

E. Also in the narthex of the St. Gheorghe-Nou church there are two tombstones made of white marble (with borders equipped with vegetal and floral ornaments): one (in the distant plan) covers the tomb of the ruler Ioan Mavrocordat (fig. 23), and the other (in the closer plan), without inscription, covers the tomb of the founder Constantin Brâncoveanu. The one on the tomb of Ioan Mavrocordat includes, in the upper part, the heraldic coat of arms of Wallachia [2] (fig. 22). The slab on the tomb of the illustrious Brâncoveanu (fig. 25) also includes, in the upper part, the coat of arms of the Cantacuzino family combined with the heraldic coat of arms of Wallachia, namely: the bicephalous eagle, from which there protrudes entirely, between shoulders and neck, the sword pointing upwards, as well as the mace, both flaked by the sun and the crescent; on the eagle's chest and stomach there appears the crucified bird [17] (fig. 24).
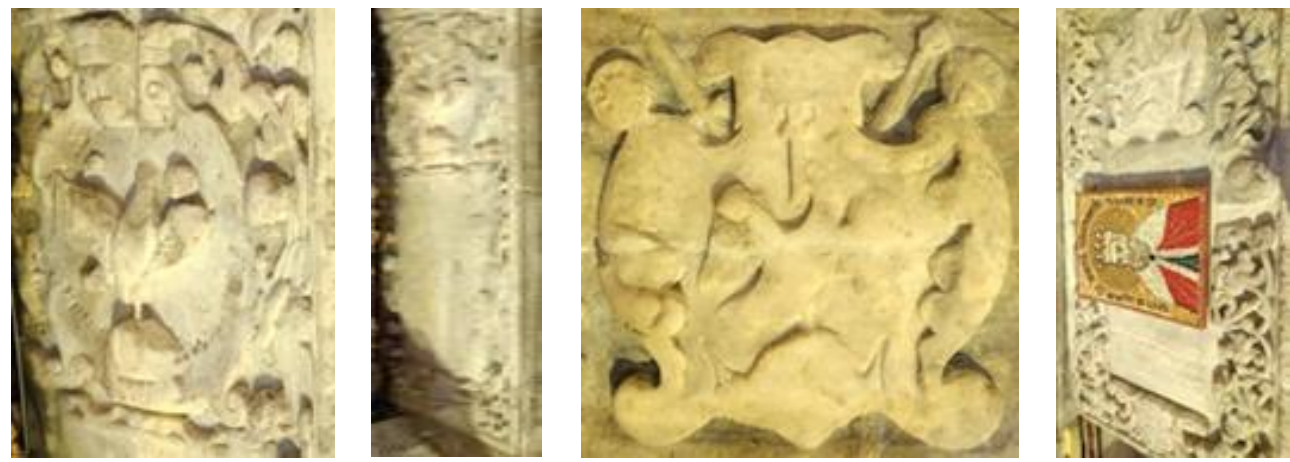

Figure 22. Figure 23. Figure 24. and Figure 25. Coats of arms on the tombstones of the rulers Ioan Mavrocordat (left) and Constantin Brâncoveanu (right).

F. On the facades of four tetrapods, placed in front of the iconostasis and on the left side of the narthex, is engraved, in different hypostases, the coat of arms of the Cantacuzins [14], namely: 1) silver bicephalous eagle, positioned in the center, holding in his right claw the sword, to the left the cruciferous globe (fig. 26), bordered by two pals laden with wavy vines (fig. 27); 2) the two-headed eagle, crowned with an open crown, with five fleurons (fig. 28), located in the lower register, which stands above a trefoil cross supported by two modilions [16] (fig. 29); 3) the bicephalous eagle, crowned with an open crown, flanked by two horns of abundance (fig. 30) and inscribed in a rectangular frame of the same metal (fig. 31); 4) two-headed eagle, crowned with an open crown, placed in two rectangular frames, one at the top (fig. 32), the other at the bottom (fig. 34) and joined by four metal pillars (fig. 33). 


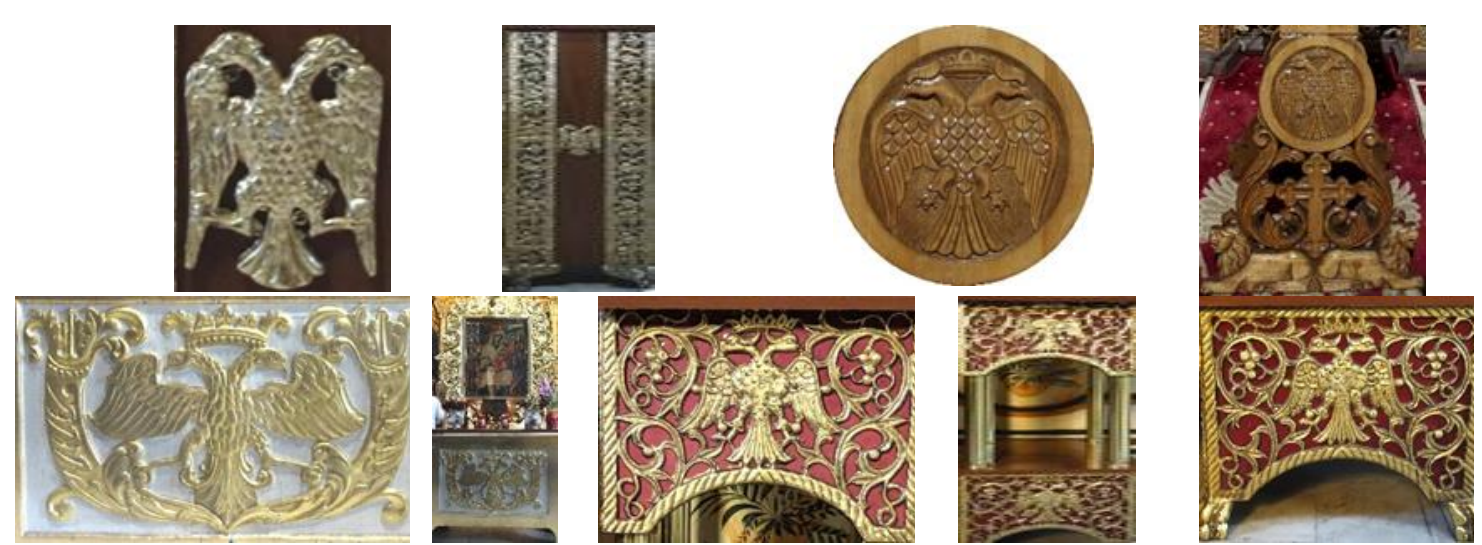

Figure 26. Figure 27. Figure 28. Figure 29. Figure 30. Figure 31. Figure 32. Figure 33. and Figure 34. The bicephalous eagle on the facades of four tetrapods inside the Church of St. Gheorghe-Nou in

Bucharest

G. On the iconostasis (fig. 36), in the upper register, in the middle, there is a small hexagon (symbol of work, rigor and collective effort) [15] of acanthus leaves, in which a round shield loaded with the bicephalous eagle is inscribed, holding in its right claw the mace, in its left the sword, all golden (fig. 35).
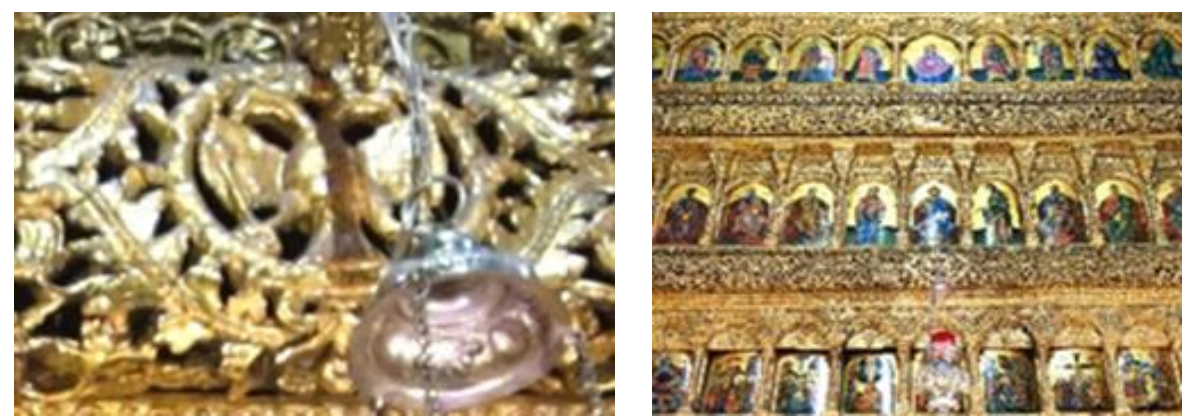

Figure 35. and Figure 36. Coat of arms of the Cantacuzino family on the iconostasis of the Church of St. Gheorghe-Nou Church in Bucharest

H. On the three purple curtains of the iconostasis (fig. 38) there is embroidered, with golden thread, the heraldic coat of arms of Wallachia (fig. 37).
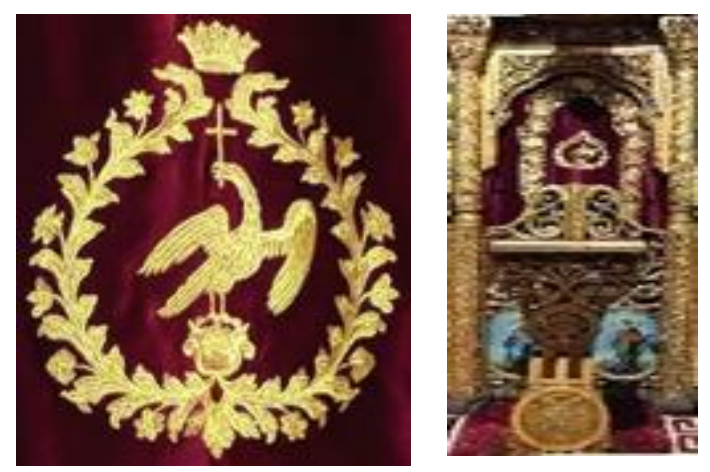

Figure 37. and Figure 38. The heraldic coat of arms of Wallachia embroidered on the three curtains from the iconostasis of the Church of St. Gheorghe-Nou in Bucharest

I. On the church floor, a few meters away from the iconostasis, in the center, made of marble mosaic, there is the heraldic coat of arms of Wallachia (fig. 39). 


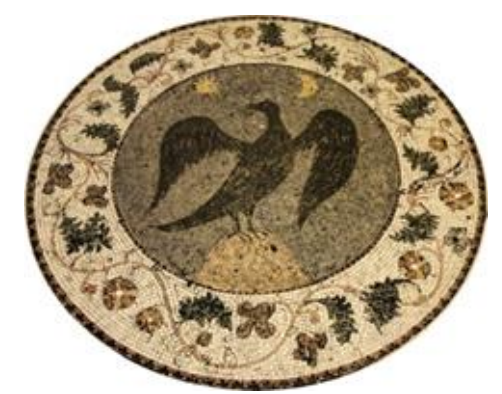

Figure 39. The heraldic coat of arms of Wallachia made of marble mosaic on the floor of the Church of St. Gheorghe-Nou in Bucharest.

J. On the gilded canopy, on the left side of the church narthex, which protects the crypts with the relics of the Holy Martyr Emilian from Durostor, of the Holy Hierarch Nicolae, the Archbishop of Lycia (right hand) [2] and the vestment of the Holy Pious Parascheva (fig. 41), in the upper register, positioned above the twisted pillars in the twist, on the corners, there is represented, in two round shields, surrounded by acanthus plants with leaves and flowers, the coat of arms of Wallachia: in the left, the bird crossed with its head turned to the wing right (fig. 40), and in the one on the right, the bird crossed with its head turned towards the left wing (fig. 42).
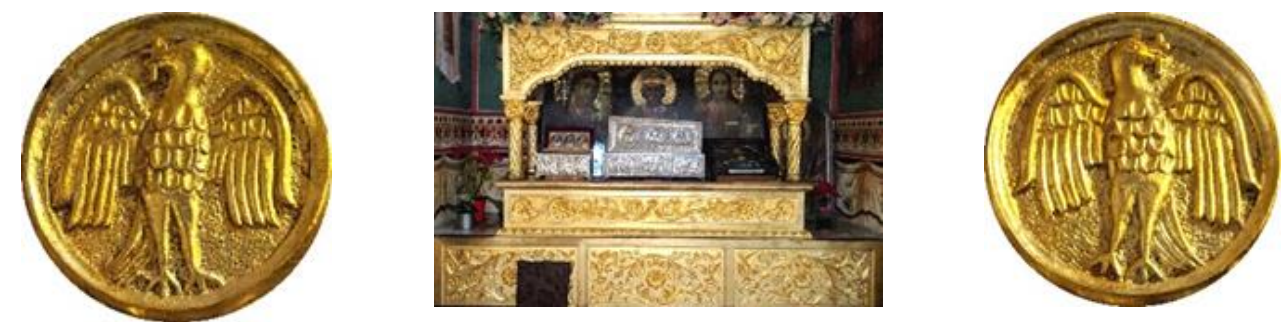

Figure 40. Figure 41. and Figure 42. The heraldic coat of arms of Wallachia (in double hypostasis) on the upper corners of the canopy that protects the crypts with the relics of the Holy Hierarch Nicholas, the Archbishop of Lycia (right hand).

K. On some tablecloths inside the church, alternating with radiant crosses, with golden vegetal and floral ornaments, on a purple background, there appears the bicephalous eagle sewn, crowned with a closed crown finished with a cross [14] (fig. 43).

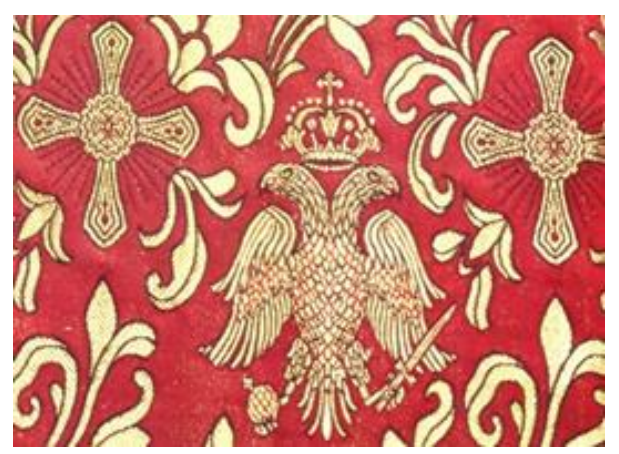

Figure 43. Bicephalous eagle multiplied on tablecloths inside the Church of St. Gheorghe-Nou in Bucharest.

L. The church flag called "prapur", attached downside to the stem, is made of purple velvet, endowed with fringes, with three golden tassels at the tops of the three tails (fig. 44) and has on the flag, embroidered, the image of Saint George on horseback and piercing with his spear (finished in cross) the dragon at the bottom, at the horse's feet (fig. 
45). In the upper register, the flag has four seraphim embroidered on the corners, and on the four sides, starting from the bottom and clockwise, the text embroidered with gold thread, written in Romanian, in capital letters: VICTORY CARRIERS, LARGE MARTYR GEORGE / PRAY ON CHRIST GOD TO SAVE OUR SOULS / AS A SAVIOR OF THE SLAVES AND THE PROTECTOR OF THE POOR / THE DOCTOR OF THE SICK, THE HELPER OF THE LEADERS.
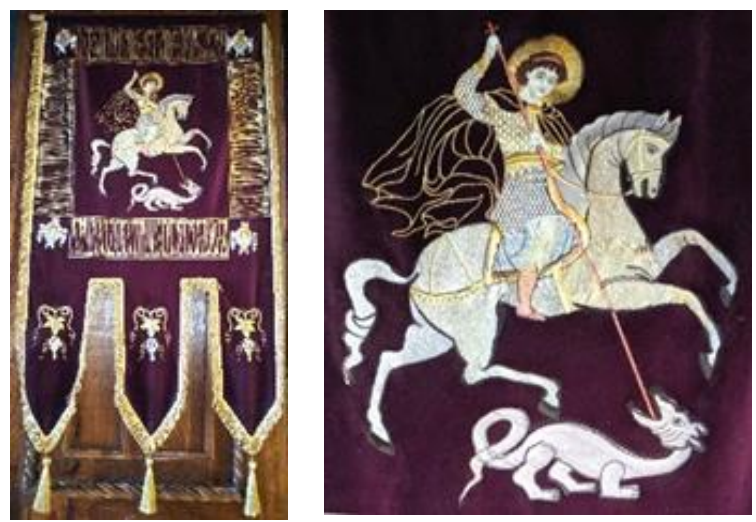

Figure 44. and Figure 45. The flag (the so-called "prapur" inside the Church of St. Gheorghe-Nou in Bucharest, in which St. Gheorghe is depicted while piercing the dragon.

\section{CONCLUSIONS}

Heraldic and vexillological springs represent a distinct section of the universal cultural heritage. The coats of arms are meant to individualize the owners and to express their duties and responsabilities. Demonstrating the scientific nature of the activity of identifying the symbols used, as well as the multitude of information transmitted by these heraldic and vexillological sources, there is an increasing interest in researching these types of signs that can serve to better understand the historical phenomena, but also to decipher the symbols by which the ancestors expressed their aspirations and thoughts. In elaborating this study, we took into account the interest that these coats of arms, blazons and flags can present for teachers, students, pilgrims, but also for tourists. Our study is also an incentive for other researchers to detect, analyze and introduce into the scientific circuit other pieces of evidence of this kind, which may be still unknown to the general public.

\section{REFERENCES}

[1] Berindei Dan \& Bonifaciu Sebastian, București: ghid turistic, Romania, 1978.

[2] Cărămizaru Emil Nedelea, Monografia Bisericii Sfântul Gheorghe-Nou din București, Romania, 2014.

[3] Colfescu Silvia, București: ghid turistic, istoric, artistic, Romania, 2006.

[4] Cristea Gherasim, Mănăstirea Hurezi, Romania, 1987.

[5] Dogaru Maria, Sigiliile mărturii ale trecutului istoric. Album sigilografic, Romania, 1976.

[6] Drăghiceanu Virgiliu, Mormântul lui Constantin Brâncoveanu Basarab Voevod, Buletinul Comisiunii Monumentelor Istorice, Romania, VII, p. 111-126, 1914.

[7] Dumitrescu Marin, Istoricul a 40 de biserici din România, Romania, 1899.

[8] Georgescu Florian, Cernovodeanu Paul \& Cebuc Alexandru, Monumente din București: ghid, Romania, 1966. 
[9] Ion Narcis Dorin, Monumente din București, Romania, 2012.

[10] Ionescu Ștefan \& Panait Panait I., Constantin Vodă Brâncoveanu: viața - domnia - epoca, Romania, 1969.

[11] Popescu Florentin, Ctitorii brâncovenești, Romania, 2004.

[12] Simionescu Dan, Pomenirea culturală a lui Const. Vodă Brâncoveanu, Preocupări literare, Romania, no. 6, p. 1-7, 1939.

[13] Szemkovics Laurențiu-Ștefan \& Teodorescu Camelia, Heraldic representations from the "Stavropoleos Monastery" in Bucharest, Quaestus Multidisciplinary Research Journal, Romania, IX, no. 16, pp. 118-127, 2020.

[14] Szemkovics Laurențiu-Ștefan \& Teodorescu Camelia (2020), Zoomorphic shields and motifs from the Colțea Church in Bucharest, Quaestus. Multidisciplinary Research Journal, nr. 16 / aprilie, anul IX, p. 128-140.

[15] Szemkovics Laurențiu-Ștefan, Teodorescu Camelia, Pop Vasile, Ducman Andrei \& Bira Nicoleta, Analysis of the heraldic elements in the building and the documents regarding the Hurezi monastery, Valcea county, Romania (1691-1714), International Scientific Conference GEOBALCANICA, Ohrid, North Macedonia, 12-14 May 2020, pp. 703-711.

[16] Szemkovics Laurențiu-Ștefan, Teodorescu Camelia, Pop Vasile, Ducman Andrei \& Gadoiu Mihaela, Analysis of the heraldic elements in the building and in the document dated 1715 that was issued for the Antim monastery in Bucharest, Romania, International Scientific Conference GEOBALCANICA, Ohrid, North Macedonia, 12-14 May 2020, p. 627-635.

[17] Șerbănescu Niculae, Mormântul voievodului martir Constantin Brâncoveanu, Biserica Ortodoxă Română, Romania, XCVIII, no. 1-2, p. 109-144, 1980.

[18] Șerbănescu Niculae, Constantin Brâncoveanu, domnul Țării Românești (1688-1714) - 275 de ani de la moartea sa martirică 1714 - 15 august - 1989, Biserica Ortodoxă Română, Romania, CVII, no. 7-10, pp. 98-158, 1989.

[19] Vergatti Radu Ștefan, Mormântul lui Constantin vodă Brâncoveanu, Argesis. Studii și comunicări, Romania, tom XVI, pp. 201-208, 2007.

[20] Vîrtosu Emil, Mormântul lui Constantin Brâncoveanu, Romania, XII, no. 1-3, pp. 207-210, 1926. 